\title{
Penggunaan Diksi dalam Kumpulan Cerita Pendek Shen Congwen dalam Kurun Tahun yang Berbeda
}

\author{
Sinar Anwar \\ STBA-PIA, Medan, North Sumatera \\ Fenny Salim \\ STBA-PIA, Medan, Sumatera Utara
}

\begin{abstract}
Abstrak
The goal of this study was to explore the dictions used in the outstanding compilation of short story written by Shen Congwen and also to find whether there was any changes of dictions made by the author within different year of publication. The short story that became the focus of this study was 棉鞋 (MianXie) published in 1925 and传 奇不奇 (Chuanqi Buqi) published in 1947. This study revealed that 棉鞋 (MianXie) in 1925 used 686 dictions which consisted of: denotation $12 \%$, connotation $4 \%$, abstract $5 \%$, general $27 \%$, odd $11 \%$, scientific $21 \%$, popular $18 \%$, slang $2 \%$. Meanwhile, 传奇不奇

(Chuanqi Buqi) in 1947 used 1625 dictions which was categorized as denotation $6 \%$, connotation $2 \%$, abstract $4 \%$, general $26 \%$, odd $9 \%$, scientific $28 \%$, popular $23 \%$, and slang $2 \%$.
\end{abstract}

Keywords: dictions, short story, Mandarin

\section{Pendahuluan}

Karya sastra adalah sebuah wujud ekspresi dari seseorang tentang apa yang ia pikirkan dan rasakan terhadap sesuatu yang dicurahkan dalam bentuk tulisan. Untuk menyampaikan pikiran dan juga emosi dalam sebuah karya sastra, digunakan katakata yang dirangkai sedemikian rupa sehingga pikiran dan perasaan penulis dapat dirasakan oleh pembaca. Eriyanto (2012:15) menyatakan bahwa pilihan kata yang tepat akan sangat berpengaruh dalam pemaknaan kata yang tersusun dalam karya yang di tulis oleh penulis. Pilihan-pilihan kata tersebut dinamakan diksi. Keraf (2008:89) mengatakan bahwa ada 12 jenis diksi, yaitu: (a) denotasi. Denotasi adalah makna sebenarnya atau berdasarkan kamus; (b) konotasi. Konotasi adalah makna kata yang mengandung arti tambahan atau merupakan makna yang bukan sebenarnya; (c) kata abstrak. Kata ini adalah kata yang maknanya tidak dapat disentuh secara fisik oleh indra manusia. Kata-kata yang termasuk kata abstrak adalah kata-kata yang merujuk pada kualitas (baik, buruk, dingin, panas), pertalian (kuantititas, jumlah, tingkatan), dan pemikiran (kecurigaan, penetapan, kepercayaan); (d) kata konkrit. Kata yang menunjuk pada sesuatu yang dapat dilihat atau dirasakan oleh satu atau lebih dari 
pancaindra; (e) kata umum. Kata umum adalah kata yang mempunyai cakupan ruang lingkup yang luas. Kata-kata umum menunjuk kepada banyak hal, kepada himpunan, dan kepada keseluruhan, misalnya: binatang, tumbuh-tumbuhan; (f) kata khusus. Kata khusus adalah kata-kata yang mengacu kepada pengarahan-pengarahan yang khusus dan konkrit. Kata khusus memperlihatkan kepada objek yang khusus, misalnya: melihat, memandang, melotot, melirik, menonton; (g) kata ilmiah. Kata ilmiah adalah kata-kata yang lazim digunakan dalam tulisan atau pembahasan ilmiah, misalnya: analogi, konservatif, fragmen; (h) kata populer. kata-kata yang umum dipakai oleh semua lapisan masyarakat, baik oleh kaum terpelajar atau oleh orang kebanyakan; (i) jargon. Jargon adalah kata-kata rahasia suatu bidang kelimuan tertentu, seperti dalam bidang seni, militer, atau kelompok khusus lainnya; (j) slang. Kata slang adalah katakata non-standard yang informal, yang disusun secara khas, bertenaga dan jenaka yang dipakai dalam percakapan, kata slang juga merupakan kata-kata yang tinggi atau murni; (k) kata asing. Kata asing adalah kata-kata yang berasal dari bahasa yang bentuk aslinya masih dipertahankan, misalnya: coca-cola, mcdonald, kfc; (1) kata serapan. Kata serapan adalah kata-kata yang berasal dari bahasa dan mengalami perubahan dari bentuk aslinya.

Dalam kesusastraan Mandarin dikenal bahwa sumber terbesar mitologi Tiongkok adalah catatan tertulis berupa literatur yang disebut Zhiguai （志怪）, yang merupakan cerita pendek. Pada masa lampau, bentuk literatur seperti ini banyak digunakan untuk menyebarkan agama yang isinya dipenuhi oleh kejadian yang tidak rasional, tentang orang suci dan dewa-dewi. Hingga saat ini, cerita pendek Tiongkok masih terus digunakan untuk mengajarkan nilai-nilai leluhur kebudayaan Tiongkok. Secara umum, cerita pendek cenderung padat dan pada tujuannya dibandingkan karyakarya fiksi lain yang lebih panjang, seperti novel. Karena singkatnya, cerita-cerita pendek yang sukses mengandalkan teknik-teknik sastra seperti tokoh, plot, tema, bahasa secara lebih luas dibandingkan dengan fiksi yang lebih panjang. Menurut Tri Priyatni (2010), cerpen adalah salah satu bentuk karya fiksi. Cerita pendek sesuai dengan namanya, memperlihatkan sifat yang serba pendek, baik peristiwa yang diungkapkan, sisi cerita, jumlah pelaku dan jumlah kata yang digunakan.

Salah satu kumpulan cerpen yang terkenal dalam kesusastraan Cina adalah karya Shen Congwen. yang berjumlah 31 karangan dan telah diterjemahkan ke dalam 
berbagai bahasa seperti bahasa Jepang, Inggris, Rusia, bahkan dimasukkan ke dalam buku pelajaran di berbagai universitas di dunia seperti Amerika, Jepang, Korea, Inggris dan belasan negara lainnya. Xiao Fei (1993:6) menyatakan, kontribusi sastra Shen Congwen terdapat dalam banyak aspek. Dalam karya sastranya novel merupakan karya terbanyak, lalu prosa, dan terdapat tidak sedikit ulasan penelitian sastra lainnya.

Berdasarkan hal tersebut, diksi yang digunakan pada kumpulan cerpen karya Shen Chongwen perlu untuk diteliti untuk memperluas pengetahuan pembaca tentang pekembangan ilmu sastra khususnya bahasa Mandarin.

\section{Metode}

Penelitian ini menggunakan desain penelitian deskriptif kualitatif. Penelitian ini merupakan penelitian yang mendeskripsikan dan menginterpretasikan data dengan kata-kata. Sumber data dalam penelitian ini adalah sebuh buku kumpulan cerita pendek karya Shen Cong Wen yang berjudul 《棉鞋》Mian Xie dan 《传奇不奇》 Chuan Qi Bu Qi. Teknik pengumpulan yang digunakan oleh peneliti adalah teknik pengumpulan dokumentasi. Pendokumentasian dalam penelitian ini dilakukan dengan cara mencatat bagian-bagian teks yang memperlihatkan bentuk penggunaan diksi dalam kumpulan cerita pendek karya Shen Congwen. Analisis yang dilakukan dalam penelitian ini adalah: (a) reduksi data yaitu membaca karangan kumpulan puisi Shen Congwen, dari awal hingga akhir secara berulang-ulang guna memahami isi yang terdapat dalam kumpulan cerita pendek tersebut, melakukan pendokumentasian dengan membuat beberapa catatan penting tentang penggunaan diksi dalam kumpulam cerita pendek karya Shen Congwen, dan mencatat data-data tentang diksi disertakan kode sumber datanya yang dimasukkan dalam kartu data; (b) penyajian data, yaitu mengklarifikasikan diksi untuk menentukan diksi yang dominan Shen Congwen dalam buku kumpulan cerita pendek karya Shen Congwen.menganalisis data sesuai dengan rumusan masalah yaitu dalam kumpulan cerita pendek karya Shen Congwen, membandingkan diksi kumpulan cerita pendek karya Shen Congwen dalam tahun yang berbeda; dan (c) penarikan kesimpulan.

\section{Hasil}

Secara teoritis, Keraf (2008:89) ada 12 jenis diksi, yaitu: (1) denotasi; (2) denotasi; (3) asbtrak; (4) konkrit; (5) umum; (6) khusus; (7) ilmiah; (8) jargon; (9) slang; (10) popular; (11) kata asing; dan (12) kata serapan. 
Secara empiris, hanya ada 8 jenis diksi yang ditermukan pada dua cerita pendek berbahasa Mandarin yang berjudul Mian xie （棉鞋） dan Chuanqi Buqi （传奇不 奇） dalam Kumpulan Cerita Pendek Karya Shen Congwen. Jenis-jenis diksi tersebut adalah: (1) denotasi 本义 (Benyi) ; (2) konotasi 引申义 (Yinshenyi);(3) abstrak 抽象 (Chouxiang)；(4) umum 一般 (Yiban);(5) khusus 个别 (Gebie);(6) ilmiah 科学 (Кexue);(7) popular 流行 (Liuxing) dan (8) Slang 俚语 (Liyu). Perbandingan penggunaan diksi pada kumpulan cerita pendek karya Shen Congwen pada tahun 1925 dengan judul Mian xie（棉鞋） dan pada tahun 1947 dengan judul 传奇不奇 (ChuanqiBuqi) dapat dilihat pada Tabel 3.1. dan Tabel 3.2. di bawah ini:

Tabel 3.1. Jenis-jenis diksi pada cerita pendek karya Shen Congwen dengan judul Mian xie（棉鞋）yang terbit pada tahun 1925

棉鞋 Mian Xie

\begin{tabular}{|c|l|l|l|l|c|c|}
\hline Data & \multicolumn{2}{|c|}{ Diksi } & $\begin{array}{c}\text { Jenis } \\
\text { Diksi }\end{array}$ & Kalimat & f & $\%$ \\
\hline 1 & 棉鞋 & Mián xié & Denotasi & 这一双棉鞋 & 81 & $12 \%$ \\
\hline
\end{tabular}




\begin{tabular}{|c|c|c|c|c|c|c|}
\hline 2 & 可怜 & kělián & Abstrak & 可怜起自己来 & 37 & $5 \%$ \\
\hline 3 & 摸抚 & mō fü & Khusus & $\begin{array}{l}\text { 还摸抚着那半磨没的 } \\
\text { 皮低 }\end{array}$ & 74 & $11 \%$ \\
\hline 4 & 磨没 & mó mò & Ilmiah & $\begin{array}{l}\text { 还摸抚着那半磨没的 } \\
\text { 皮低 }\end{array}$ & 143 & $21 \%$ \\
\hline 5 & 去年 & qùnián & Umum & 去年十二月 & 186 & $27 \%$ \\
\hline 6 & 见心斋 & $\begin{array}{llll}\text { jiàn } & x \overline{1} n \\
z & h & \bar{a} & i\end{array}$ & Populer & $\begin{array}{l}\text { 㡾风亭，或见心离， } \\
\text { 或.....不拘那一处： }\end{array}$ & 120 & $18 \%$ \\
\hline 7 & 谁个 & shéi gè & Slang & $\begin{array}{l}\text { 谁个能无意中掉一个 } \\
\text { 皮夹来让我拾呢? }\end{array}$ & 16 & $2 \%$ \\
\hline 8 & 放光 & $\begin{array}{l}\text { fàng } \\
\text { guāng }\end{array}$ & Konotasi & $\begin{array}{l}\text { 同时眼睛放光，有奇 } \\
\text { 异色 }\end{array}$ & 29 & $4 \%$ \\
\hline \multicolumn{5}{|c|}{ Total } & 686 & $100 \%$ \\
\hline
\end{tabular}


Tabel 3.2. Jenis-jenis diksi pada cerita pendek karya Shen Congwen dengan judul 传 奇不奇 (ChuanqiBuqi) terbit pada tahun 1947

\begin{tabular}{|c|c|c|c|c|c|c|}
\hline \multicolumn{7}{|c|}{ 传奇不奇 ChuanqiBuqi } \\
\hline Data & \multicolumn{2}{|c|}{ Diksi } & \multirow{2}{*}{$\begin{array}{r}\text { Jenis } \\
\text { Diksi } \\
\text { Denotasi }\end{array}$} & \multirow{2}{*}{$\begin{array}{l}\text { Kalimat } \\
\text { 从山下附近人家抬了个 } \\
\text { 车谷子的木风驴上山 } \\
\text { 来 }\end{array}$} & \multirow{2}{*}{$\begin{array}{ll} & \mathbf{f} \\
10 & 0\end{array}$} & \multirow{2}{*}{$\begin{array}{l}\% \\
6 \%\end{array}$} \\
\hline 1 & 抬 & tái & & & & \\
\hline 2 & 悲 恻 & bēi cè & Abstrak & $\begin{array}{l}\text { 却俨然把面前两人浸入 } \\
\text { 一 种无可形容的悲恻 } \\
\text { 里 }\end{array}$ & $6 \quad 2$ & $4 \%$ \\
\hline 3 & 安 慰 & ānwèi & Khusus & $\begin{array}{l}\text { 又只听到师爷安慰大队 } \\
\text { 长 }\end{array}$ & 146 & $9 \%$ \\
\hline 4 & $\begin{array}{c}\text { 得 饶 人 } \\
\text { 处且 饶 } \\
\text { 人 }\end{array}$ & $\begin{array}{l}\text { dé ráo rén } \\
\text { chù qiě } \\
\text { ráo rén }\end{array}$ & Ilmiah & 得饶人处且 饶人 & 463 & $28 \%$ \\
\hline 5 & 浓烟 & nóng yān & Umum & $\begin{array}{l}\text { 用炭火慢慢燃起有毒浓 } \\
\text { 烟 }\end{array}$ & 422 & $26 \%$ \\
\hline 6 & $\begin{array}{c}\text { 照 前 - } \\
\text { 回 }\end{array}$ & $\begin{array}{l}\text { zhào qián } \\
\text { yī huí }\end{array}$ & Populer & $\begin{array}{l}\text { 因此故意照前一回那么 } \\
\text { 说, “老太太, 谢谢 } \\
\text { 你 }\end{array}$ & 367 & $23 \%$ \\
\hline 7 & 命 根 根 & $\begin{array}{l}\text { mìnggēn } \\
\text { gēn }\end{array}$ & Slang & $\begin{array}{l}\text { 放冬生一条生路, 杨大 } \\
\text { 娘家只有这一个命根根 }\end{array}$ & 3 & $2 \%$ \\
\hline 8 & $\begin{array}{c}\text { 天 有 眼 } \\
\text { 睛 }\end{array}$ & $\begin{array}{l}\text { tiān yǒu } \\
\text { yănjīng }\end{array}$ & Konotasi & $\begin{array}{l}\text { 人做好事有好报应，天 } \\
\text { 有 眼 睛 的 ! }\end{array}$ & 26 & $2 \%$ \\
\hline & & & Total & & 1.625 & $100 \%$ \\
\hline
\end{tabular}

Tabel diatas menunjukkan perbandingan penggunaan diksi pada cerita pendek Shen Congwen pada tahun 1925 dan 1947, pada tahun 1925 urutan jenis diksi yang paling banyak digunakan adalah jenis diksi umum, ilmiah, popular, denotasi, khusus, abstrak, konotasi, slang, sedangkan pada tahun 1947 adalah ilmiah, umum, popular, khusus, denotasi, abstrak dan slang. 


\section{Pembahasan}

Berdasarkan data diatas dapat diketahui bahwa Shen Congwen dalam kumpulan cerita pendek karyanya yang berjudul 棉鞋 (Mianxie) menggunakan 8 jenis diksi berjumlah 686 diksi yaitu: diksidenotasisebanyak 81, diksi konotasi sebanyak 29, diksi abstrak sebanyak 37, diksi umum sebanyak 186, diksi khusus sebanyak 74, diksi ilmiah sebanyak 143, diksi popular sebanyak 120, dan diksi slang sebanyak 16 buah, dan cerita pendek yang berjudul 传奇不奇 (ChuanqiBuqi) menggunakan 8 jenis diksi berjumlah 1625 diksi yaitu: diksi denotasi sebanyak100, diksi konotasi sebanyak 26, diksi abstrak sebanyak 62, diksi umum sebanyak 422, diksi khusus sebanyak 146, diksi ilmiah sebanyak 463, diksi popular sebanyak 367, dan diksi slang sebanyak 39 buah.

Berdasarkan hasil penelitian diatas, penulis mendapati terjadinya perubahan penggunaan diksi oleh Shen Congwen dalam tahun yang berbeda, yaitu: jenis diksi denotasi yang pada cerita pendek 棉鞋 (Mianxie) terbitan 1925 sebanyak 12\% pada cerita pendek传奇不奇 (ChuanqiBuqi) berkurang menjadi 6\%, diksi konotasi yang pada cerita pendek棉鞋 (Mianxie) terbitan 1925 sebanyak 4\% pada cerita pendek传奇不奇 (ChuanqiBuqi) berkurang menjadi 2\%, diksi abstrak yang pada cerita pendek 棉鞋 (Mianxie) terbitan 1925 sebanyak 5\% pada cerita pendek传奇不奇 (ChuanqiBuqi) berkurang menjadi 4\%, diksi umumyang pada cerita pendek棉鞋 (Mianxie) terbitan 1925 sebanyak 27\% , pada cerita pendek传奇不奇 (ChuanqiBuqi) berkurang menjadi 26\%, diksi khusus yang pada cerita pendek棉鞋 (Mianxie) terbitan 1925 sebanyak 11\% , pada cerita pendek传奇不奇 (ChuanqiBuqi) berkurang menjadi 9\%, diksi ilmiah yang pada cerita pendek棉鞋 (Mianxie) terbitan 1925 sebanyak 21\%, pada cerita pendek传奇 不奇 (ChuanqiBuqi) bertambah menjadi 28\%, diksi populer yang pada cerita pendek棉 鞋 (Mianxie) terbitan 1925 sebanyak 18\% , pada cerita pendek传奇不奇 (ChuanqiBuqi) bertambah menjadi 23\%, diksi slang yang pada cerita pendek棉鞋 
(Mianxie) terbitan 1925 sebanyak 2\%, pada cerita pendek传奇不奇 (ChuanqiBuqi) tidak bertambah dan tidak berkurang sebanyak $2 \%$.

\section{Daftar Pustaka}

Eriyanto. 2012. Analisis Wacana: Pengantar Analisis Teks Media. Cetakan ke-3. Yogyakarta: Lkis Group.

Keraf, G.2007. Diksi dan Gaya Bahasa. Jakarta : PT. Gramedia Pustaka Utama.

Tri Priyatni, Endah. 2010. Membaca Sastra Dengan Ancangan Literasi Kritis. Jakarta: Bumi Aksara.

Xiao Fei. 1994. Prosa Shen Congwen. Terbitan Siaran Televisi Republik Rakyat China. 